\title{
PERSEPSI RISIKO DAN NIAT PENGGUNAAN ALAT KONTRASEPSI
}

\author{
Ayu Marlika Leni Putri $\left.{ }^{*}\right)$, Megawati Simanjuntak ${ }^{1}$ \\ ${ }^{1}$ Departemen IImu Keluarga dan Konsumen, Fakultas Ekologi Manusia, Institut Pertanian Bogor, \\ Bogor 16680, Indonesia \\ ${ }^{*}$ E-mail: ayumarlikaleniputri@gmail.com
}

\begin{abstract}
Abstrak
Upaya untuk menurunkan angka kelahiran salah satunya dapat dilakukan melalui penggunaan alat kontrasepsi. Penelitian ini bertujuan untuk menganalisis hubungan akses informasi, pengetahuan, persepsi risiko dengan niat penggunaan alat kontrasepsi. Responden dalam penelitian ini adalah wanita usia subur (15-49 tahun) yang sudah menikah dan belum menggunakan alat kontrasepsi yang diambil dengan metode purposive sampling sebanyak 60 orang. Data dikumpulkan melalui wawancara menggunakan kuesioner. Hasil menunjukkan bahwa lama pendidikan suami, lama pendidikan wanita usia subur, usia suami wanita usia subur, usia wanita usia subur, jumlah sumber informasi, dan sumber informasi yang dipercaya berhubungan dengan pengetahuan wanita usia subur terhadap alat kontrasepsi. Namun, tidak ada variabel yang berhubungan dengan persepsi risiko. Persepsi risiko penggunaan alat kontrasepsi hormonal dengan nonhormonal berbeda signifikan pada risiko fungsi, fisik, keuangan, sosial, waktu dan hilangya kesempatan, akan tetapi, persepsi risiko alat kontrasepsi hormonal dengan nonhormonal secara keseluruhan tidak berbeda secara signifikan. Sementara itu, niat penggunaan berhubungan dengan lama pendidikan suami.
\end{abstract}

Kata kunci: informasi, keluarga berencana, niat penggunaan, pengetahuan, persepsi risiko

\section{Perceived Risk and Intention of Using Contraceptive}

\begin{abstract}
One of efforts to reduce the birth rate can be conducted by using contraceptive. This study aimed to analyze the relationship among information access, knowledge, perceived risk, and the intention to use contraceptive. The participant of this study were 60 women at reproductive age (15-49 years) who never used contraceptive and selected by purposive sampling method. Data was collected through interview by a questionnaire. The results indicated that the education level and the age of husband and wife had a correlation significantly with the knowledge level of contraceptive use. In addition, the knowledge level about contraceptive use also related to the number source and the trusted source of information. The results also revealed that there was not variable correlated with perceived risk. Perceived risk of between hormonal and nonhormonal contraceptives had significant difference on functional, physical, financial, social, time, and opportunity cost dimention but not at perceived risk in several. Meanwhile, intention to use had positive correlation with husband of wife's education level.
\end{abstract}

Keywords: family planning, information, intention of the use, knowledge, perceived risk

\section{PENDAHULUAN}

Setiap tahunnya jumlah penduduk Indonesia mengalami peningkatan (BPS, 2010). Faktor utama yang memengaruhi laju pertumbuhan penduduk adalah tingkat kelahiran. Pemerintah berupaya untuk menekan laju pertumbuhan penduduk melalui Badan Kordinasi Keluarga Berencana Nasional (BKKBN) yang merupakan lembaga pemerintah nonkementerian yang berada di bawah dan bertanggung jawab kepada Presiden (Perpres No. 62 tahun 2010). BKKBN menunjukkan bahwa pada tahun 2013 terdapat 8.500.247
Pasangan Usia Subur (PUS) yang merupakan peserta Keluarga Berencana (KB).

Laju pertumbuhan tertinggi di Provinsi Jawa Barat dengan jumlah penduduk tertinggi berdasarkan sensus penduduk adalah Kabupaten Bogor, yaitu sebesar 4.771.932 jiwa (BPS, 2013). Akan tetapi Kabupaten Bogor juga menjadi kabupaten dengan PUS paling banyak yang tidak menggunakan alat kontrasepsi. Padahal, penggunaan alat kontrasepsi merupakan bagian dari program Keluarga Berencana yang ditujukan untuk mengatur kelahiran. 
Penggunaan alat kontrasepsi dipengaruhi oleh akses informasi, pengetahuan, persepsi risiko, dan niat penggunaan alat kontrasepsi. Pengetahuan ini diperoleh melalui paparan informasi yang diakses dari berbagai sumber. Informasi yang dipaparkan tersebut dapat merupakan risiko ataupun manfaat dari alat kontrasepsi. Persepsi risiko adalah manfaat negatif berdasarkan persepsi konsumen (Sumarwan, 2011). Persepsi tersebut diantaranya adalah efek samping dari alat kontrasepsi. Hal ini berhubungan dengan ketidakinginan wanita menggunakan alat kontrasepsi (Utami et al., 2011). Maria et al. (2005) menambahkan bahwa penggunaan alat kontrasepsi berdampak pada perubahan berat badan.

Sebelum seseorang berkehendak, biasanya akan dipengaruhi oleh seberapa besar niat seseorang untuk melakukannya. Niat penggunaan alat kontrasepsi berkaitan dengan berbagai faktor personal maupun luar personal calon pengguna. Niat ini dapat mengalami penurunan jika alat kontrasepsi justru memberikan risiko. Beberapa faktor lainnya yang memengaruhi wanita tidak ingin menggunakan alat kontrasepsi adalah pilihan metode kontrasepsi, pemberian informasi, dan kualitas pelayanan alat kontrasepsi (Herlinawati, 2004). Kemungkinan menurunnya niat penggunaan alat ini merupakan masalah yang berhubungan dengan informasi, pengetahuan, dan persepsi risiko.

Berdasarkan pemaparan permasalahan tersebut, penelitian ini penting dilakukan. Penelitian ini bertujuan untuk menganalisis hubungan akses informasi, pengetahuan, dan persepsi risiko dengan niat penggunaan alat kontrasepsi. Penelitian ini juga bertujuan untuk menganalisis perbedaan persepsi risiko antara alat kontrasepsi hormonal dengan alat kontrasepsi nonhormonal.

\section{METODE}

Desain penelitian ini adalah cross sectional. Kecamatan Dramaga, Kabupaten Bogor, Provinsi Jawa Barat dipilih secara purposive untuk menjadi lokasi penelitian. Contoh dalam penelitian ini adalah 60 orang Wanita Usia Subur (WUS) berusia 15-49 tahun yang sudah menikah dan belum pernah menggunakan alat kontrasepsi. Contoh dipilih secara purposive.

Data primer dikumpulkan melalui pengisian kuesioner. Data meliputi karakteristik individu, karakteristik keluarga, akses informasi, persepsi risiko pengetahuan, dan niat penggunaan. Data karakteristik individu dan keluarga meliputi usia suami dan istri, lama pendidikan yang ditempuh suami dan istri, jenis pekerjaan suami dan istri, pendapatan keluarga, dan jumlah anak.

Analisis data dalam penelitian ini meliputi analisis deskriptif dan inferensial. Analisis deskriptif meliputi rata-rata, standar deviasi, nilai minimum, dan nilai maksimum. Analisis inferensial meliputi uji korelasi Pearson, uji ChiSquare, dan uji beda $t$. Uji korelasi Pearson dan Chi-Square digunakan untuk menganalisis hubungan akses informasi, pengetahuan, dan persepsi risiko dengan niat penggunaan alat kontrasepsi. Sedangkan uji beda $t$ digunakan untuk menganalisis perbedaan persepsi risiko antara alat kontrasepsi hormonal dengan alat kontrasepsi nonhormonal.

\section{HASIL}

\section{Karakteristik Individu dan Keluarga}

Rata-rata usia responden adalah 24,07 tahun sedangkan suami berusia 27,87 tahun. Secara umum, suami berusia lebih tua dibandingkan responden. Sementara itu, ratarata lama pendidikan responden adalah 10,23 tahun sedangkan suami adalah 10,67 tahun. Tingkat pendidikan yang ditempuh suami lebih tinggi dibandingkan responden. Persentase terbesar suami responden (38,3\%) berprofesi sebagai pegawai swasta dan sebagian besar responden $(83,3 \%)$ adalah ibu rumah tangga.

Hampir seluruh keluarga responden memiliki pendapatan per kapita lebih besar atau sama dengan Rp226.097 per bulan atau termasuk kategori tidak miskin dengan rata-rata Rp917.638,89 per bulan artinya rata-rata pendapatan per kapita lebih besar dari garis kemiskinan (GK). Lebih dari tiga perlima $(68,3 \%)$ belum memiliki anak dan sisanya $(31,7 \%)$ sudah memiliki anak.

\section{Akses Informasi}

Jumlah sumber informasi tentang alat kontrasepsi cukup bervariasi dengan jumlah minimum adalah dua dan maksimum adalah enam sumber informasi. Hasil penelitian ini menunjukkan bahwa persentase terbesar $(96,7 \%$ dan $93,3 \%)$ yang menjadi sumber informasi alat kontrasepsi adalah teman/tetangga dan keluarga. Lebih dari dua perlima responden $(45,0 \%)$ mempercayai informasi yang diberikan oleh bidan atau dokter yang dianggap sebagai seseorang berdasarkan 
pekerjaan, pendidikan, dan pengalamannya. Selain itu, hampir seluruh responden $(95,0 \%)$ mendapat informasi tentang risiko alat kontrasepsi oleh sumber informasinya. Hampir seluruh responden $(98,3 \%$ dan $96,7 \%)$ mengetahui alat kontrasepsi suntik dan pil.

\section{Pengetahuan}

Lebih dari tiga perempat responden $(78,0 \%)$ memiliki tingkat pengetahuan yang rendah. Informasi yang diberikan oleh kepada responden dapat berasal dari pengalaman pribadi, pengalaman orang lain, atau informasi yang diterima dari sumber informasi lainnya. Hasil ini menunjukkan bahwa pengetahuan Wanita Usia Subur (WUS) tentang alat kontrasepsi masih perlu ditingkatkan sebagai upaya untuk memberikan informasi yang tepat tentang manfaat dan penggunaan alat kontrasepsi.

\section{Persepsi Risiko}

Persepsi risiko dalam penelitian ini dinilai dari beberapa dimensi, yaitu dimensi fungsi, fisik, keuangan, psikologi, sosial, waktu, dan dimensi hilangnya kesempatan. Pada hasil penelitian ini menemukan bahwa persepsi risiko terhadap alat kontrasepsi hormonal dan nonhormonal pada dimensi fungsi, fisik, keuangan, waktu, sosial, dan hilangnya kesempatan memiliki perbedaan secara signifikan $(p \leq 0,01)$. Hasil penelitian ini menunjukkan bahwa nilai rata-rata persepsi risiko fungsi, fisik, dan waktu alat kontrasepsi hormonal lebih tinggi daripada alat kontrasepsi nonhormonal, sedangkan persepsi risiko dimensi keuangan, sosial, dan hilangnya kesempatan alat kontrasepsi nonhormonal lebih tinggi daripada alat kontrasepsi hormonal (Tabel 1).

Tabel 1 Koefisien uji beda ( $p$-value) antara rata-rata skor persepsi risiko alat kontrasepsi hormonal dan nonhormonal

\begin{tabular}{lr}
\hline \multicolumn{1}{c}{ Dimensi } & $p$-value \\
\hline Dimensi fungsi & $0,000^{*}$ \\
Dimensi fisik & $0,000^{*}$ \\
Dimensi keuangan & $0,000^{*}$ \\
Dimensi psikologi & 0,328 \\
Dimensi sosial & $0,000^{*}$ \\
Dimensi waktu & $0,003^{*}$ \\
Dimensi hilangnya & $0,009^{*}$ \\
kesempatan & \\
\hline Total & 0,231 \\
\hline Keterangan: ${ }^{*}$ signifikan pada $p<0,01$ &
\end{tabular}

Meskipun demikian, secara keseluruhan persepsi risiko alat kontrasepsi hormonal dan nonhormonal tidak berbeda secara signifikan. Namun, nilai rata-rata persepsi risiko alat kontrasepsi nonhormonal lebih tinggi daripada alat kontrasepsi hormonal. Hampir seluruh responden $(95,0 \%)$ memiliki persepsi risiko yang rendah.

\section{Niat Penggunaan}

Niat berperilaku merupakan tingkat yang menentukan sejauh mana seseorang berniat untuk melakukan atau tidak melakukan perilaku tertentu pada waktu yang akan datang (Davis, Bagozzi, \& Marshow, 1989). Persentase terbesar penelitian ini menunjukkan bahwa hampir delapan dari sepuluh responden $(78,3 \%)$ berniat menggunakan alat kontrasepsi dan 21, 7 persen tidak berniat.

\section{Hubungan antara karakteristik Individu, karakteristik keluarga, dan Akses Informasi dengan pengetahuan}

Hasil uji korelasi pada penelitian ini memperlihatkan bahwa variabel karakteristik individu dan karakteristik keluarga yang berhubungan signifikan positif dengan pengetahuan responden tentang alat kontrasepsi yaitu usia suami, usia responden, lama pendidikan suami, dan lama pendidikan responden.

Sementara itu, variabel akses informasi yang berhubungan signifikan positif dengan pengetahuan tentang alat kontrasepsi adalah jumlah sumber informasi dan sumber informasi yang dipercayai. Koefisien uji hubungan antara karakteristik responden, karakteristik keluarga responden, dan akses informasi dengan pengetahuan disajikan pada Tabel 2 .

Hasil ini menunjukkan bahwa semakin bertambah usia suami dan istri serta semakin lama pendidikan suami dan istri maka semakin baik pengetahuan wanita usia subur tentang alat kontrasepsi KB. Jumlah sumber informasi yang diperoleh wanita usia subur berhubungan signifikan positif dengan pengetahuan. Hal ini berarti bahwa semakin banyak jumlah informasi maka semakin baik pengetahuan tentang alat kontrasepsi. Adapun sumber informasi dari bidan/dokter merupakan sumber informasi yang lebih dipercayai Wanita Usia Subur (WUS) dibandingkan dengan sumber informasi lain (bukan bidan/dokter). 
Tabel 2 Koefisien uji hubungan antara karakteristik responden, karakteristik keluarga responden, dan akses informasi dengan pengetahuan

\begin{tabular}{|c|c|c|}
\hline No & Variabel & Koefisien \\
\hline 1 & $\begin{array}{l}\text { Usia suami responden } \\
\text { (tahun) }\end{array}$ & $0,318^{*}$ \\
\hline 2 & Usia responden (tahun) & $0,322^{*}$ \\
\hline 3 & $\begin{array}{l}\text { Lama pendidikan suami } \\
\text { responden (tahun) }\end{array}$ & $0,350^{* *}$ \\
\hline 4 & $\begin{array}{l}\text { Lama pendidikan } \\
\text { responden (tahun) }\end{array}$ & $0,464^{* *}$ \\
\hline 5 & $\begin{array}{l}\text { Pekerjaan responden } \\
\text { (1:tidak bekerja, } \\
0: \text { bekerja) }\end{array}$ & $d f=8 ; p=0,300$ \\
\hline 6 & Besar keluarga (orang) & 0,157 \\
\hline 7 & $\begin{array}{l}\text { Pendapatan per } \\
\text { kapita/bulan } \\
\text { (Rp/orang/bulan) }\end{array}$ & 0,160 \\
\hline 8 & $\begin{array}{l}\text { Lama pernikahan } \\
\text { (bulan) }\end{array}$ & 0,024 \\
\hline 9 & $\begin{array}{l}\text { Jumlah sumber } \\
\text { informasi (skor) }\end{array}$ & $0,387^{\star *}$ \\
\hline 10 & $\begin{array}{l}\text { Banyak macam } \\
\text { informasi (skor) }\end{array}$ & 0,188 \\
\hline 11 & $\begin{array}{l}\text { Sumber informasi yang } \\
\text { dipercayai } \\
\text { (1:bidan/dokter, } 0: \\
\text { bukan bidan/dokter) }\end{array}$ & $d f=8 ; p=0,004^{\star *}$ \\
\hline \multicolumn{3}{|c|}{$\begin{array}{l}\text { Keterangan: } \\
\text { **signifikan pada } p \leq 0,01 \text {, }{ }^{2} \text { signifikan pada } \leq 0,05 \\
\text { Nomor } 5 \text { dan } 11 \text { diuji menggunakan uji chi square } \\
\text { Nomor } 1,2,3,4,6,7,8,9 \text {, dan } 10 \text { diuji menggunakan uj } \\
\text { korelasi Pearson }\end{array}$} \\
\hline
\end{tabular}

Hubungan antara Karakteristik Individu, Karakteristik Keluarga, Akses Informasi, dan Pengetahuan dengan Persepsi Risiko

Persepsi risiko tidak berhubungan signifikan dengan usia suami, usia responden, lama pendidikan suami, lama pendidikan responden, pekerjaan responden, besar keluarga, pendapat-an per kapita per bulan, lama pernikahan, pengetahuan, jumlah sumber informasi, banyak macam informasi dan sumber informasi yang dipercayai $(p>0,05)$.

\section{Hubungan antara Karakteristik Individu, Karakteristik Keluarga, Pengetahuan, dan Persepsi Risiko dengan Niat Penggunaan}

Analisis korelasi yang disajikan pada Tabel 3 menunjukkan bahwa terdapat hubungan yang signifikan positif antara lama pendidikan suami dengan niat penggunaan terhadap alat kontrasepsi. Hal ini mengindikasikan bahwa pertambahan lama pendidikan suami mengikuti pendidikan formal maka semakin tinggi niat WUS untuk menggunakan alat kontrasepsi.
Tabel 3 Hubungan antara karakteristik individu, karakteristik keluarga, akses informasi, pengetahuan, dan persepsi risiko dengan niat penggunaan

\begin{tabular}{|c|c|c|}
\hline No & Variabel & Niat penggunaan \\
\hline 1 & $\begin{array}{l}\text { Usia suami responden } \\
\text { (tahun) }\end{array}$ & 0,462 \\
\hline 2 & Usia responden (tahun) & 0,238 \\
\hline 3 & $\begin{array}{l}\text { Lama pendidikan suami } \\
\text { responden (tahun) }\end{array}$ & $0,039^{*}$ \\
\hline 4 & $\begin{array}{l}\text { Lama pendidikan } \\
\text { responden (tahun) }\end{array}$ & 0,115 \\
\hline 5 & $\begin{array}{l}\text { Pekerjaan responden } \\
\text { (1:tidak bekerja, } \\
0: \text { bekerja) }\end{array}$ & 0,123 \\
\hline 6 & $\begin{array}{l}\text { Besar keluarga } \\
\text { responden (orang) }\end{array}$ & 0,144 \\
\hline 7 & $\begin{array}{l}\text { Lama pernikahan } \\
\text { (bulan) }\end{array}$ & 0,105 \\
\hline 8 & $\begin{array}{l}\text { Pendapatan per } \\
\text { kapita/bulan } \\
\text { (Rp/orang/bulan) }\end{array}$ & 0,678 \\
\hline 9 & Pengetahuan (skor) & 0,545 \\
\hline 10 & $\begin{array}{l}\text { Jumlah sumber } \\
\text { informasi (skor) }\end{array}$ & 0,462 \\
\hline 11 & $\begin{array}{l}\text { Banyak macam } \\
\text { informasi (skor) }\end{array}$ & 0,841 \\
\hline 12 & $\begin{array}{l}\text { Sumber informasi yang } \\
\text { dipercayai } \\
\text { (1:bidan/dokter, 0: bukan } \\
\text { bidan/dokter) }\end{array}$ & 0,925 \\
\hline 13 & Persepsi risiko (skor) & 0,678 \\
\hline
\end{tabular}

Keterangan:

*Signifikan pada $p \leq 0,05$

\section{PEMBAHASAN}

Hasil penelitian menunjukkan bahwa pengetahuan berhubungan positif dengan lama pendidikan dan usia wanita usia subur. Hal ini menunjukkan bahwa semakin bertambah usia dan semakin tinggi pendidikan wanita usia subur maka akan meningkatkan pengetahuan yang dimiliki wanita usia subur tentang alat kontrasepsi. Hasil ini sejalan dengan Narzary (2009) yang mengungkapkan pengetahuan terkait alat kontrasepsi meningkat secara konstan dengan bertambahnya usia dan pendidikan istri. Selain itu, peningkatan pendidikan dan usia suami juga berhubungan dengan meningkatnya pengetahuan terkait alat kontrasepsi. Hal ini dapat terjadi karena suami menyampaikan pengetahuan yang dimiliki kepada wanita usia subur melalui diskusi.

Hasil uji korelasi menunjukkan bahwa sumber informasi yang dipercayai oleh responden berhubungan dengan pengetahuan yang dimiliki. Wanita usia subur menyimpan informasi terkait alat kontrasepsi sebagai 
pengetahuannya hanya informasi yang berasal dari bidan atau dokter. Penelitian Lunsen, Arnolds, \& Maris (1994) juga menemukan bahwa dokter adalah sumber yang paling dipercayai informasinya. Paparan dari sumbersumber informasi terkait pesan keluarga berencana (KB) memiliki hubungan positif dengan pengetahuan alat kontrasepsi (Odimegwu \& Raimi, 2003). Hal ini sejalan dengan hasil penelitian yang menunjukkan bahwa banyaknya jumlah sumber informasi berhubungan positif dengan pengetahuan. Selain itu, dokter atau bidan merupakan sumber informasi yang lebih dipercaya dibandingkan sumber informasi lain.

Hasil penelitian menyatakan bahwa jumlah sumber informasi tentang alat kontrasepsi tidak berhubungan dengan persepsi risiko yang dimiliki wanita usia subur. Persepsi risiko yang terbentuk karena pengalaman memberikan efek yang kuat terhadap persepsi risiko konsumen sedangkan sumber informasi tidak memberikan efek yang nyata terhadap persepsi risiko konsumen (Wahlberg \& Sjoberg, 2000). Sumber informasi ini memberikan isi informasi tertentu kepada konsumen. Substansi informasi inilah yang akan memengaruhi persepsi risiko konsumen (Hu \& Han, 2011). Selain itu, persepsi risiko juga dapat terbentuk karena pengetahuan yang kurang terhadap produk tersebut (Bena \& Pelau, 2010). Teori ini tidak sejalan dengan hasil penelitian yang menunjukkan bahwa pengetahuan responden terkait alat kontrasepsi tidak berhubungan dengan persepsi risiko.

Haque dan Soonthorndhada (2009) menyatakan bahwa persepsi risiko meningkat seiring dengan meningkatnya level pendidikan. Hal ini menunjukkan bahwa pemahaman yang meluas terkait alat kontrasepsi dan semakin kritisnya menangkap informasi terkait risiko alat kontrasepsi pada responden yang memiliki level pendidikan yang tinggi. Selain itu, Chauvin, Hermand, \& Mullet (2007) juga menyatakan bahwa usia memiliki hubungan yang positif dengan persepsi risiko seseorang. Perbedaan hasil penelitian dengan penelitian terdahulu disebabkan persepsi risiko responden menyebar merata pada kategori rendah, sehingga usia responden, usia suami responden, lama pendidikan responden, lama pendidikan suami responden, pekerjaan responden, besar keluarga, pendapatan per kapita per bulan dan lama pernikahan tidak berhubungan dengan persepsi risiko responden terhadap alat kontrasepsi.
Hasil Penelitian ini menunjukkan bahwa pengetahuan tidak memiliki hubungan dengan niat penggunaan alat kontrasepsi. Berbeda dengan hasil penelitian yang dilakukan Chen dan Chen (2011) bahwa pengetahuan terkait alat kontrasepsi memiliki pengaruh langsung terhadap niat penggunaan alat kontrasepsi. Akses informasi yang dimiliki oleh wanita usia subur tidak berhubungan dengan niat penggunaan alat kontrasepsi. Hasil penelitian ini tidak sejalan dengan hasil penelitian yang dilakukan oleh Jato et al. (1999) bahwa beberapa paparan media (radio, logo, koran, poster, leaflet, dan televisi) mampu memengaruhi wanita untuk menggunakan alat kontrasepsi. Persepsi risiko yang tinggi dapat menyebabkan konsumen menunda atau menghindari penggunaan atau pembelian suatu produk (Cunningham, Gerlach, \& Harper, 2004). Seorang istri akan mengontrol kelahiran anak ketika terjadi perubahan besar keluarga (Grace, 2009). Oleh sebab itu, besar keluarga bertindak sebagai katalis dalam menggunakan alat kontrasepsi.

Hasil penelitian menunjukkan bahwa lama pendidikan suami berhubungan dengan niat wanita usia subur untuk menggunakan alat kontrasepsi. Artinya, semakin tinggi pendidikan yang ditempuh suami akan meningkatkan niat penggunaan alat kontrasepsi. Sejalan dengan hasil Okezie (2010) menyatakan bahwa usia suami dan pendidikan suami memiliki hubungan yang positif dengan penggunaan alat kontrasepsi dan besar keluarga, sedangkan pendapatan keluarga berhubungan negatif dengan niat penggunaan alat kontrasepsi. Sementara itu, hasil penelitian ini tidak sejalan dengan penelitian Tawiah (1997) yang menunjukkan bahwa pendidikan suami tidak ada kaitannya dengan penggunaan alat kontrasepsi.

\section{SIMPULAN DAN SARAN}

Semakin bertambah usia suami, usia wanita usia subur, lama pendidikan yang ditempuh suami, lama pendidikan wanita usia subur, jumlah sumber informasi, dan sumber yang dipercaya oleh wanita usia subur maka akan meningkatkan pengetahuan tentang alat kontrasepsi. Tidak ada variabel dalam penelitian ini yang berhubungan dengan persepsi risiko. Semakin lama pendidikan yang ditempuh suami maka akan meningkatkan niat dalam penggunaan alat kontrasepsi. 
Persepsi risiko yang berbeda signifikan berdasarkan tipe alat kontrasepsi (hormonal dan nonhormonal) adalah risiko fungsi, fisik, sosial, keuangan, waktu, dan hilangnya kesempatan. Namun, persepsi risiko secara keseluruhan berdasarkan tipe alat kontrasepsi tidak berbeda signifikan. Hasil dalam penelitian ini menunjukkan bahwa hampir seluruh wanita usia subur memiliki persepsi risiko yang rendah terkait alat kontrasepsi. Lebih dari tiga perempat wanita usia subur berniat untuk menggunakan alat kontrasepsi untuk satu tahun mendatang.

\section{DAFTAR PUSTAKA}

Bena, I., \& Pelau, C. (2010). The risk perception for consumer segments in ecommerce and its implication for marketing strategy. E-journal of Protection of Consumers' Rights and Interest, 12(28), 373-387. Diambil dari http://www.amfiteatrueconomic.ro/temp/Art icle9 70.pdf. [diunduh 8 Agu 2012].

[BKKBN] Badan Kordinasi Keluarga Berencana Nasional. (2011). Evaluasi statistik rutin Kabupaten/Kota. Jawa Barat, ID: BKKBN.

[BPS] Badan Pusat Statistik. (2010). Laju pertumbuhan penduduk. Jakarta, ID: BPS.

(2013). Laju

Pertumbuhan Penduduk. Jakarta, ID: BPS.

Chauvin, B., Hermand D., \& Mullet, E. (2007). Risk perception and personality facets. Journal of Risk Analysis, 27(1), 171-185. doi: 10.1111/j.1539-6924.200 6.00867-x.

Chen, R., \& Hen, F. (2003). Using brand knowledge to understand consumers' intention to adopt an online retailer [Abstract]. International Journal of Services technology and management Absract, 4(4), 464-47.

Cunningham, L. F., Gerlach, J., \& Harper, M. D. (2004). Assessing perceived risk of consumers in internet airline reservations services. E-journal of Air Transportation, 9(1). Diambil dari http://ntl.bts.gov/ [diunduh 6 Jun 2012].

Davis, F. D., Bagozzi, R. P., \& Marshaw, P. R. (1989). User acceptance of computer technology a comparison of two theoretical models. E-journal of Management Science, 35(8).

Grace, K. (2009). A comparative analysis of contraceptive use and intent in Guatemala. E-journal of Max Planck Institute for Demographic Research. Diambil dari http://www.demogr.mpg.de/papers/working /wp-2009036. Pdf. [diunduh 08 Jun 2012].

Haque, M. R., \& Soonthorndhada, A. (2009). Risk perception and condom-use among Thai youths: Findings from Kanchanaburi demographic surveillance system site in Thailand [Abstract]. International Journal of Health PopulNutr, 27(6), 772-783. [diunduh 20 Sep 2012].

Herlinawati. (2004). Pengaruh komunikasi, informasi, edukasi, dan kualitas pelayanan kontrasepsi terhadap drop out penggunaan alat kontrasepsi di Desa Setupatok (tesis). Universitas Diponegoro, Semarang.

Hu, W., \& Han, J. (2011). Factors influencing the efficacy of food safety communication [Absract]. Information Technology, Computer Engineering and Management Sciences (ICM), 4, 292-294.

Jato, M. N., Simbakalia, C., Tarasevich, J. M., Awasum, D. N., Kihinga, C. N. B., \& Ngirwamungu, E. (1999). The Impact of multimedia family planning promotion on the contraceptive behavior of women in Tanzania. E-journal of International Family Planning Perspectives. 25(2). Diambil dari http://www.guttmacher.org/pubs/journals/2 506099.html. [diunduh 5 Jun 2012].

Lunsen, R. H. W. V., Arnolds, H. T., \& Maris, M. G. M. V. (1994). Choices and changes incontraceptive behavior: The role of information sources. E-journal of Elsevier. 23(3), 197-202. [diunduh 28 Apr 2012].

Maria, S., Hasnah, M. N., \& Thabita, L. M. (2005). Dampak penggunaan alat kontrasepsi hormonal terhadap perubahan berat badan pada akseptor keluarga berencana. (skripsi). Politeknik Kesehatan Makasar, Makasar.

Narzary, P. K. (2009). Knowledge and use of contraception among currently married adolescent women in India. Study and Home Community Sciences, 3(1), 43-49.

Odimegwu, C. O., \& Raimi, M. O. (2003). Media mix and contraceptive behavior of sexually active Nigerians. E-journal of Development and Society, 32(1), 61-75.

Okezie, C. A., Ogbe, A. O., \& Okezie, C. R. (2010). Socio-economic determinants of contraceptive use among rural women in Ikwuano Local Government Area of Abia State, Nigeria, International NGO Journal, 5(4), 74-77. 
[Perpres RI] Peraturan Presiden Republik Indonesia. (2010). Peraturan Presiden Republik Indonesia Nomor 62 Tahun 2010 tentang Badan Kependudukan dan Keluarga Berencana Nasional.

Sumarwan U. (2011). Perilaku konsumen: Teori dan penerapannya dalam pemasaran. Jakarta, ID: Gahlia Indonesia.

Tawiah, E. O. (2012). Factors affecting contraceptive use in Ghana. Journal Biosocial Sciences, 29(2), 141-149. Diambil dari:http://www.mtholyoke.edu/ rusib20a/a sinath/contrac Ghana.pdf. [diunduh 4 Jun 2012].

Utami, S., Sukesi, \& Ayu, W. H. (2011). Hubungan efek samping dengan kejadian drop out pada akseptor AKDR di Poli KB I RSUD dr. Soetomo Surabaya. E-journal Penelitian Kesehatan Suara Forikes, 2(3).

Wahlberg, A. A., \& Sjoberg, L. (2000). Risk perception and the media. E-journal of Risk Research, 3(1), 31-50. 